\title{
Ciąża, poród i połóg u nosicielki hemofilii
}

\section{Pregnancy, delivery and puerperium in hemophilia carrier}

\author{
Magdalena Górska-Kosicka1 ${ }^{1}$, Edyta Odnoczko², Jerzy Windyga ${ }^{1,2}$ \\ ${ }^{1}$ Klinika Zaburzeń Hemostazy i Chorób Wewnętrznych, Instytut Hematologii i Transfuzjologii, Warszawa \\ ${ }^{2}$ Zakład Hemostazy i Chorób Metabolicznych, Instytut Hematologii i Transfuzjologii, Warszawa
}

\begin{abstract}
Streszczenie
Spośród wrodzonych niedoborów czynników krzepnięcia krwi tylko hemofilia A i B dziedziczq sie $w$ sposób recesywny sprzężony z ptciq. Objawy skazy krwotocznej występuja gtównie u mężczyzn, kobiety zaś najczéściej sa bezobjawowymi nosicielkami cechy hemofilii. Istnieja jednak stany kliniczne, w których ryzyko krwawienia u nosicielek hemofilii wzrasta; należa do nich między innymi poród i potóg. Ustalenie rozpoznania nosicielstwa hemofilii przed ciaża umożliwia wybór optymalnej strategii postepowania w okresie okotoporodowym, dzięki której minimalizuje sie ryzyko wystapienia powiktań krwotocznych. Zadaniem ginekologa dziatajacego w zespole lekarskim opiekujacym sie cieżarna nosicielka hemofili jest ustalenie sposobu rozwiazania ciaży. Podejmujac decyzje o sposobie porodu, bierze sie pod uwage zarówno bezpieczeństwo matki, jak i potencjalnie obciażonego hemofiliq noworodka. Bardzo pomocna w dokonaniu wyboru między porodem droga naturalna a cieciem cesarskim jest diagnostyka prenatalna, której wynik potwierdza lub wyklucza hemofilie u ptodu. Jednym z najpowazniejszych powiktań krwotocznych u nosicielek hemofili jest krwotok poporodowy. Dlatego każda nosicielka hemofilii wymaga w potogu wzmożonego nadzoru ginekologiczno-hematologicznego, a w przypadku stwierdzenia zmniejszonej aktywności czynnika VIII lub IX - zastosowania odpowiedniej profilaktyki przeciwkrwotocznej, najcześciej za pomoca koncentratu niedoborowego czynnika krzepnięcia. U noworodków ptci meskiej urodzonych przez nosicielki hemofilii konieczne sq jak najszybsze oznaczenie aktywności czynnika VIII lub IX oraz wnikliwa obserwacja pod katem obecności objawów skazy krwotocznej.
\end{abstract}

Słowa kluczowe: nosicielka hemofilii, ciąża, poród, diagnostyka prenatalna, leczenie substytucyjne

Hematologia 2016; 7, 1: 14-22

\section{Abstract}

Among inherited bleeding disorders only hemophila $A$ and $B$ are recessive $X$-linked conditions. Bleeding diathesis affects males while females are mostly asymptomatic carriers of the hemophilia trait. There are however clinical conditions such as delivery and puerperium when hemophilia carriers are at inceased risk of hemorrhage. Wherever possible (i.e. knowledge of family history of hemophilia), in order to avoid bleeding complications genetic testing to confirm the status of suspected carrier should be performed in advance of planned pregnancy. The task of the obstetrician in charge of a pregnant hemophilia carrier is to recommend prenatal diagnosis to confirm or exclude hemophilia in early pregnancy and then to consider maternal and foetal risks and benefits

Adres do korespondencji: Magdalena Górska-Kosicka, Klinika Zaburzeń Hemostazy i Chorób Wewnętrznych, Instytut Hematologii i Transfuzjologii, ul. Gandhi 16, 02-776 Warszawa, tel. 22349 61 08, faks 2234961 59, e-mail: magdagorska@tlen.pl 
as basis for selection of the most appropriate mode of delivery (cesarean versus natural delivery). As hemophilia carriers are at increased risk of postpartum hemorrhage, in puerperium they should be under comprehensive gynecological and hematological monitoring for factor VIII/IX levels and hemostatic treatment (factor VIII/IX concentrate) should be administered whenever necessary. A coagulation screen and appropriate factor levels assay should be performed on cord blood samples of all male infants delivered by hemophilia carriers. All at risk neonates should be carefully observed for sings of bleeding.

Key words: hemophilia carrier, pregnancy, delivery, prenatal diagnostics, replacement therapy

Hematologia 2016; 7, 1: 14-22

\section{Wprowadzenie}

Hemofilia to uwarunkowana genetycznie skaza krwotoczna, której istotą jest niedobór czynnika krzepnięcia VIII (FVIII, factor VIII) w przypadku hemofilii A i czynnika krzepnięcia IX (FIX, factor IX) w przypadku hemofilii B. Przyczyną hemofilii są mutacje w genach kodujących FVIII (F8) lub FIX (F9). Ponieważ geny $F 8$ i $F 9$ znajdują się na chromosomie płciowym $\mathrm{X}$, to hemofilia dziedziczy się w sposób recesywny sprzężony $z$ płcią i $z$ tego powodu objawy choroby występują głównie u mężczyzn, kobiety natomiast są nosicielkami cechy hemofilii [1]. Hemofilia A występuje $z$ częstością 1 na 5000 urodzonych chłopców, zaś hemofilia B ujawnia się u około 1 na 30000 urodzonych chłopców [2]. Warto dodać, że skazy krwotoczne pokrewne hemofilii, a więc wynikające $z$ uwarunkowanego genetycznie niedoboru pozostałych czynników krzepnięcia krwi, dziedziczą się autosomalnie, zatem w równym stopniu występują u kobiet i mężczyzn.

W niektórych przypadkach nosicielstwo hemofilii można rozpoznać na podstawie analizy rodowodu bez wykonywania badań laboratoryjnych. Za pewne nosicielki hemofilii uznaje się córki mężczyzn chorych na hemofilię, matki co najmniej dwóch synów chorych na hemofilię, matki jednego chorego syna, jeśli inny krewny choruje na hemofilię, oraz matki jednego chorego syna, jeśli w rodzinie jest potwierdzona nosicielka hemofilii [3, 4]. Za potencjalne nosicielki hemofilii uważa się córki pewnych nosicielek hemofilii, siostry mężczyzn chorych na hemofilię, siostry, ciotki lub kuzynki pewnych nosicielek hemofilii oraz matki jednego chorego syna $z$ rodziny bez wywiadu hemofilii $[4,5]$. W Ogólnopolskim Rejestrze Wrodzonych Skaz Krwotocznych prowadzonym w Instytucie Hematologii i Transfuzjologii jest zarejestrowanych 55 nosicielek hemofilii A oraz 28 nosicielek hemofilii B (dane $z$ 8.02.2016 r.).

Aktywność koagulacyjna czynnika VIII (FVIII:C, FVIII coagulant activity) w osoczu zdro- wych osób mieści się w przedziale 40-150 jednostek międzynarodowych w decylitrze (jm./dl), czyli 40-150\% normy [1, 6]. Zależnie od nasilenia niedoboru czynnika VIII wyróżnia się ciężką (FVIII:C < $1 \mathrm{jm} . / \mathrm{dl}$ ), umiarkowaną (FVIII:C $1-5 \mathrm{jm} . / \mathrm{dl}$ ) i łagodną (FVIII:C od $>5$ do $<40 \mathrm{jm} . / \mathrm{dl}$ ) postać hemofilii A [3]. Podział ten obowiązuje zarówno przy rozpoznawaniu choroby, jak i stanu nosicielstwa [3, 5]. Aktywność koagulacyjna czynnika IX (FIX:C, FIX coagulant activity) w osoczu osób zdrowych także wynosi 40-150 jm./dl, a podział hemofilii B na trzy stopnie ciężkości i ogólne zasady rozpoznawania hemofilii $\mathrm{B}$ u nosicielek tej skazy są analogiczne do hemofilii A.

Rozpoznanie nosicielstwa hemofilii A nie powinno się opierać wyłącznie na oznaczeniu aktywności czynnika VIII, ponieważ u większości nosicielek FVIII:C pozostaje w granicach normy. Prawdopodobieństwo występowania stanu nosicielstwa hemofilii A można w przybliżeniu oszacować, porównując aktywność czynnika VIII z zawartością antygenu czynnika von Willebranda (VWF:Ag, von Willebrand factor antigen) w osoczu badanej kobiety. Przy stosunku FVIII:C do VWF:Ag poniżej 0,5 można rozpoznać nosicielstwo hemofilii A $z$ ponad 90-procentowym prawdopodobieństwem [1]. Jednak pewne rozpoznanie nosicielstwa hemofilii A jest możliwe wyłącznie na podstawie wyniku badań genetycznych identyfikujących mutację sprawczą. $Z$ kolei w przypadku hemofilii B prawidłowa aktywność czynnika IX w osoczu także nie wyklucza stanu nosicielstwa. Ponieważ VWF nie ma żadnego wpływu na aktywność FIX, to u potencjalnych nosicielek hemofilii B tylko badania genetyczne pozwalają jednoznacznie potwierdzić lub wykluczyć nosicielstwo.

Moment wykonania badań w kierunku nosicielstwa pozostaje tematem kontrowersyjnym. Uzasadnione jest oznaczenie aktywności czynnika VIII lub IX w dzieciństwie, gdyż u nosicielki mogą występować objawy skazy krwotocznej wymagające leczenia hemostatycznego [7]. Natomiast badania 
genetyczne powinny być wykonywane w momencie, gdy potencjalna nosicielka jest w stanie podjąć samodzielną i świadomą decyzję. Genetyczne potwierdzenie nosicielstwa hemofilii we wczesnym dzieciństwie może spowodować negatywny efekt psychologiczny poprzez obniżenie poczucia własnej wartości czy wywołanie strachu przed chorobą. Przeprowadzenie badań genetycznych zaleca się przed planowaną ciążą, aby uniknąć inwazyjnych badań prenatalnych u kobiet, u których nosicielstwo zostanie wykluczone [8].

\section{Opieka w czasie ciąży}

Fizjologicznie u kobiet w ciąży aktywność czynnika VIII zwiększa się, a najbardziej dynamiczny wzrost obserwuje się w III trymestrze. Podobnie dzieje się u nosicielek hemofilii A. Wartość FVIII:C może ulec u nich podwojeniu w porównaniu $z$ aktywnością sprzed ciąży, dzięki czemu obniża się ryzyko krwawień $[9,10]$. Jednak u pacjentek z wyjściowo małą aktywnością FVIII wartości te mogą nie osiąnnąć normy $[10,11]$. U nosicielek hemofilii B ciąża nie wpływa znacząco na aktywność czynnika IX $[9,10]$.

Aktywność FVIII lub FIX w osoczu ciężarnej nosicielki ocenia się zwykle tuż po potwierdzeniu ciąży oraz w 28. i 34. tc. [12]. Dzięki 3-krotnym oznaczeniom w przypadku wystąpienia krwawienia czy konieczności wykonania pilnego zabiegu inwazyjnego znana jest aktualna aktywność niedoborowego czynnika krzepnięcia, umożliwiająca wdrożenie odpowiedniego leczenia hemostatycznego [10]. Poza koniecznością oznaczenia aktywności FVIII lub FIX oraz zaplanowania leczenia hemostatycznego w okresie okoloporodowym prowadzenie niepowikłanej ciąży u nosicielki hemofilii nie różni się znacząco od opieki nad zdrowymi kobietami w ciąży. Największe obawy lekarzy są związane $z$ ryzykiem utraty ciąży, wystąpieniem powikłań krwotocznych oraz odpowiednim zabezpieczeniem hemostatycznym w przypadku konieczności wykonania zabiegu inwazyjnego ( $\mathrm{z}$ różnych wskazań).

Dane $z$ piśmiennictwa, w którym oceniano częstość poronień u nosicielek hemofilii, nie pozwalają na jednoznaczne stwierdzenie, że ryzyko utraty ciąży w tej grupie pacjentek jest zwiększone. W pojedynczych analizach wykazano, że poronienia występują u około $31 \%$ nosicielek hemofilii A i 17\% nosicielek hemofilii B [11]. Nie ma natomiast wątpliwości, że krwawienie związane $z$ poronieniem u nosicielki hemofilii może być bardziej intensywne niż u zdrowej kobiety (poniżej przedstawiono zasady leczenia krwawień w tej grupie pacjentek) [13].
Nie ma jednoznacznych dowodów wskazujących na zwiększone ryzyko krwawień u nosicielek hemofilii we wczesnym okresie ciąży. Krwotok przedporodowy (APH, antepartum hemorrhage), definiowany jako krwawienie $z$ dróg rodnych występujące między 20.tc. a porodem, obserwuje się w przypadku 2-5\% wszystkich ciąż [11]. Częstość występowania APH wśród nosicielek hemofilii oraz w populacji ogólnej jest porównywalna $[12,14]$. W większości przypadków APH to następstwo patologii łożyska - występowania łożyska przodującego lub jego przedwczesnego odklejenia. Rzadziej źródłem krwawienia jest dolny odcinek dróg rodnych, czyli szyjka macicy i pochwa (stany zapalne, nadżerka szyjki macicy, nowotwory) $[11,15]$. U każdej ciężarnej nosicielki hemofilii krwawiącej $z$ dróg rodnych należy poszukiwać ginekologicznych przyczyn krwawienia; jeśli aktywność FVIII lub FIX jest mniejsza niż 50 jm./dl, to należy zastosować koncentrat niedoborowego czynnika krzepnięcia [1, 10, 12]. Preferowane są rekombinowane koncentraty FVIII i FIX. Zastosowanie koncentratów osoczopochodnych niesie potencjalne (choć niskie) ryzyko zakażenia matki wirusem zapalenia wątroby typu A i parwowirusem B19. Wirusy te nie posiadają otoczki lipidowej i dlatego trudniej poddają się procedurom inaktywacji stosowanym przy wytwarzaniu koncentratów czynników krzepnięcia z ludzkiego osocza $[12,16]$. Wewnątrzmaciczna infekcja tymi wirusami może spowodować obrzęk płodowy prowadzący do obumarcia płodu [16].

Dożylne wstrzyknięcie koncentratu FVIII $\mathrm{w}$ dawce $1 \mathrm{jm} . / \mathrm{kg}$ mc. powoduje zwiększenie aktywności tego czynnika w osoczu osoby $z$ hemofilią A przeciętnie o $2 \mathrm{jm}$./dl. Dawkowanie koncentratu FVIII zależy od stopnia niedoboru FVIII u nosicielki, a zasady podawania tego koncentratu są takie same jak u pacjentów $z$ hemofilią A o odpowiednim stopniu ciężkości (tab. 1). U krwawiącej nosicielki aktywność FVIII należy zwiększyć i utrzymywać powyżej $50 \mathrm{jm}$./dl, a leczenie substytucyjne kontynuuje się do czasu ustapienia krwawienia [1, 10, 12]. Dokładny czas stosowania leczenia, częstość podawania koncentratu oraz jego dawki w kolejnych dniach zależą od sytuacji klinicznej oraz wyników oznaczeń aktywności FVIII w osoczu nosicielki (monitoring laboratoryjny) [5]. Laboratoryjne monitorowanie leczenia polega na codziennym pomiarze aktywności FVIII w próbce krwi pobranej około godzinę (nadir dobowej aktywności FVIII) przed planowanym wstrzyknięciem koncentratu czynnika VIII [1].

U osób $z$ łagodną hemofilią A zwiększenie aktywności czynnika VIII w osoczu można osiągnąć, 
Tabela 1. Leczenie hemostatyczne stosowane w okresie ciąży i porodu u nosicielek hemofilii A (zmodyfikowano na podstawie [4]) Table 1. Hemostatic treatment in hemophilia A carriers during pregnancy and delivery (modified according to [4])

\begin{tabular}{|l|c|c|c|}
\hline \multirow{2}{*}{ Wskazanie } & \multicolumn{2}{|c|}{$\begin{array}{c}\text { Orientacyjne dawkowanie koncentratu FVIII [jm./kg mc.] zależenie od wyjściowej } \\
\text { aktywności koagulacyjnej FVIII (FVIII:C) u nosicielki hemofilii A }\end{array}$} \\
\cline { 2 - 4 } & FVIII:C < 5 jm./dI & FVIII:C 5-30 jm./dI & FVIII:C > 30 jm./dI \\
\hline Krwawienie w ciąży & 50 & 40 & 30 \\
\hline Zabiegi inwazyjne w ciąży & 50 & 40 & 30 \\
\hline Poród siłami natury & 50 & 40 & 30 \\
\hline Cięcie cesarskie & 50 & 40 & 30 \\
\hline Krwawienie poporodowe & 25 & $\begin{array}{c}\text { Zalecana DDAVP } \\
0,3 \mu \text { g/kg mc. }\end{array}$ & $\begin{array}{c}\text { Zalecana DDAVP } \\
0,3 \mu \mathrm{g} / \mathrm{kg} \mathrm{mc} .\end{array}$ \\
\hline
\end{tabular}

Uwaga! Częstotliwość dawek oraz czas leczenia zależą od sytuacji klinicznej oraz aktywności FVIII w osoczu pacjentki

FVIII (factor VIII) - czynnik VIII; FVIII:C (factor VIII coagulant activity) - aktywność koagulacyjna czynnika VIII; DDAVP (1-desamino-8-D-arginine vasopresin) — desmopresyna

Tabela 2. Leczenie hemostatyczne stosowane w okresie ciąży i porodu u nosicielek hemofilii B (zmodyfikowano na podstawie [4]) Table 2. Hemostatic treatment in hemopilia B carriers during pregnancy and delivery (modified according to [4])

\begin{tabular}{|l|c|c|}
\hline \multirow{2}{*}{ Wskazanie } & \multicolumn{2}{|c|}{$\begin{array}{c}\text { Orientacyjne dawkowanie koncentratu FIX (jm./kg mc.) zależenie od wyjściowej } \\
\text { aktywności koagulacyjnej FIX (FIX:C) u nosicielki hemofilii B }\end{array}$} \\
\cline { 2 - 3 } & FIX:C < $\mathbf{0 0 ~ j m . / d l ~}$ & FIX:C > 30 jm./dl \\
\hline Krwawienie w ciąży & 80 & 50 \\
\hline Zabiegi inwazyjne w ciąży & 80 & 50 \\
\hline Poród siłami natury & 80 & 50 \\
\hline Cięcie cesarskie & 80 & 50 \\
\hline Krwawienie poporodowe & 50 & 15 \\
\hline
\end{tabular}

Uwaga! Częstotliwość dawek oraz czas leczenia zależą od sytuacji klinicznej oraz aktywności FX w osoczu pacjentki

FIX (factor IX) - czynnik IX; FIX:C (factor IX coagulant activity) - aktywność koagulacyjna czynnika IX

podając desmopresynę (DDAVP, 1-desamino-8-D-arginine vasopresin). W przeciwieństwie do wydzielanej przez przysadkę wazopresyny, DDAVP, pobudzając głównie receptory wazopresynowe typu V2, minimalnie wpływa na naczynia krwionośne, w związku z czym ryzyko skurczu naczyń i w konsekwencji niewydolności łożyska prowadzącej do poronienia lub przedwczesnego porodu jest niewielkie $[12,17,18]$. W nielicznych danych $z$ piśmiennictwa jest mowa o bezpiecznym stosowaniu DDAVP u kobiet w ciąży. Mannucci [17] stosował desmopresynę u 32 kobiet w I i II trymestrze ciąży (27 nosicielek hemofilii oraz 5 pacjentek $z$ chorobą von Willebranda), a jedynymi działaniami niepożądanymi przypisywanymi DDAVP były ból głowy i zaczerwienienie twarzy. Podobnie w analizie przeprowadzonej przez Trigga i wsp. [18], obejmującej 51 pacjentek $z$ zaburzeniami hemostazy w I i w początkowym okresie II trymestru ciąży, nie stwierdzono niekorzystnego wpływu DDAVP na przebieg ciąży ani stan płodu. Stosowanie desmopresyny wiąże się z ryzykiem hiponatremii u matki i u płodu, dlatego kobietom poddanym terapii tym lekiem zaleca się ograniczenie podaży płynów i monitorowanie stężenia sodu w surowicy [12]. W 3-7 dni od rozpoczęcia podawania DDAVP dochodzi do wyczerpania magazynów śródbłonkowych FVIII, w związku z czym dłuższe stosowanie desmopresyny jest nieskuteczne (zjawisko tachyfilaksji). W przypadku gdy pacjentka wymaga leczenia hemostatycznego dłużej niż przez 3-5 dni, zwykle od początku stosuje się koncentrat FVIII.

U krwawiących ciężarnych nosicielek hemofilii $\mathrm{B} z$ aktywnością FIX poniżej $50 \mathrm{jm}$./dl postępuje się podobnie jak u nosicielek hemofilii A. Podaje się koncentrat FIX, tak aby utrzymać jego aktywność w osoczu powyżej $50 \mathrm{jm}$./dl. Dożylne wstrzyknięcie $1 \mathrm{jm} . / \mathrm{kg}$ mc. koncentratu FIX osobie $\mathrm{z}$ niedoborem tego czynnika powoduje wzrost jego aktywności w osoczu tej osoby przeciętnie o $1 \mathrm{jm}$./dl. Dawkowanie koncentratu FIX przedstawiono w tabeli 2. Desmopresyna nie zwiększa aktywności FIX i nie ma zastosowania w leczeniu nosicielek hemofilii B $[1,12,16]$. 
Dodatkowo, w celu zahamowania krwawień, można wykorzystać leki wspomagające, przede wszystkim antyfibrynolityczne, które wykazują dużą skuteczność w hamowaniu krwawień śluzówkowych [11, 15]. Obecnie w Polsce dostępny jest kwas traneksamowy (TXA, tranexemic acid). Jego skuteczność i bezpieczeństwo w leczeniu krwawień u kobiet w ciąży potwierdzono w kilku badaniach klinicznych i obserwacyjnych [19]. Jednym $z$ możliwych działań niepożądanych TXA jest wzrost ryzyka wystąpienia powikłań zakrzepowo-zatorowych. Ponieważ ciąża per se zwiększa ryzyko wystąpienia zakrzepicy żylnej, to kobiety w ciąży, w tym nosicielki hemofilii, otrzymujące TXA wymagają obserwacji pod kątem wystąpienia objawów żylnej choroby zakrzepowo-zatorowej.

\section{Diagnostyka prenatalna}

Diagnostyka prenatalna pozwala na rozpoznanie chorób płodu we wczesnym okresie ciąży. Eksperci uważają, że jeśli istnieje taka możliwość, to badania prenatalne powinno się wykonać u każdej ciężarnej nosicielki hemofilii $[1,12]$. Potwierdzenie lub wykluczenie hemofilii u płodu pozwala ustalić optymalny sposób prowadzenia i zakończenia cią$\dot{z} y$ oraz postępowania u noworodka w pierwszych dniach jego życia [1].

Wyróżnia się inwazyjne i nieinwazyjne metody diagnostyki prenatalnej. Metody inwazyjne obejmują biopsję trofoblastu (11.-14. tydzień ciąży [tc.]), amniopunkcję (15.-18. tc.) i kordocentezę (po 18 tc.) [2, 5]. Zarówno biopsja trofoblastu, jak i amniopunkcja pozwala na uzyskanie DNA płodu, które wykorzystuje się do przeprowadzenia diagnostyki molekularnej hemofilii oraz określenia płci dziecka [20, 21]. Warunkiem wykluczenia lub potwierdzenia hemofilii w prenatalnej diagnostyce genetycznej jest znajomość mutacji odpowiedzialnej za tę chorobę w badanej rodzinie [2, 22]. Jeżeli biopsja trofoblastu lub amniopunkcja nie są możliwe do wykonania, to pobiera się krew pępowinową płodu (kordocenteza) w celu oznaczenia aktywności FVIII lub FIX. W hemofilii B metoda ta ma istotne ograniczenie, gdyż zawartość FIX u płodu jest fizjologicznie mała, a właściwa interpretacja wyniku może być trudna lub niemożliwa [1]. Około 19. tc. aktywność FVIII u zdrowego płodu wynosi średnio $40 \mathrm{jm} . / \mathrm{dl}$, a FIX - $10 \mathrm{jm} . / \mathrm{dl}$. W przypadku kordocentezy istnieje ryzyko domieszki krwi matki, co może stanowić dodatkowe utrudnienie w interpretacji uzyskanego wyniku (krew matki można odróżnić od krwi płodu, oznaczając średnią objętość erytrocytów, która wynosi > 120 fl u pło- du i ok. 90 fl u matki) [9, 12]. Badania inwazyjne stwarzają ryzyko poronienia, które w przypadku biopsji trofoblastu szacuje się na około $1 \%$, aminopunkcji - na $2 \%$, a kordocentezy - na $6 \%$ [1]. U nosicielek $z$ aktywnością FVIII lub FIX poniżej $50 \mathrm{jm} . / \mathrm{dl}$ przed każdym zabiegiem inwazyjnym stosuje się substytucję koncentratu niedoborowego czynnika krzepnięcia, pod kontrolą jego aktywności w osoczu [12]. Aktywność oznacza się 30 minut po zakończeniu podawania koncentratu. Jeśli uzyska się zadowalającą aktywność czynnika krzepnięcia, to można przystąpić do zabiegu (tab. 1,2). Ponieważ opisane wyżej procedury mogą spowodować przeciek krwi płodu do łożyska naczyniowego matki, to u kobiet $\mathrm{z}$ grupą krwi Rh (-) zaleca się podanie immunoglobuliny anty-D [3, 9, 11]. Immunoglobulinę tę podaje się domięśniowo w czasie nieprzekraczającym 72 godzin od wykonania zabiegu [23].

W nieinwazyjnej diagnostyce prenatalnej u nosicielek hemofilii, poza badaniami ultrasonograficznymi, cennych informacji dostarcza analiza wolnego płodowego DNA we krwi matki (ffDNA, free fetal $D N A$ ). Badanie to służy określaniu płci płodu w I trymestrze ciąży [2, 22]. Wykrycie płci żeńskiej na wczesnym etapie ciąży może się przyczynić do podjęcia decyzji o zaniechaniu przeprowadzenia inwazyjnych badań prenatalnych [2].

\section{Poród u nosicielki hemofilii}

Poród jest krytycznym momentem zarówno dla nosicielki hemofilii, jak i płodu obciążonego skazą krwotoczną. $Z$ tego powodu tok postępowania planuje się $z$ odpowiednim wyprzedzeniem. Poród powinien się odbywać w ośrodku współpracującym $z$ laboratorium wykonującym oznaczenia aktywności FVIII i FIX [12, 16]. U każdej rodzącej jest wskazane wykonanie przesiewowych testów hemostazy, oznaczenie aktywności niedoborowego czynnika krzepnięcia oraz zabezpieczenie krwi do ewentualnej transfuzji. Jeżeli z powodu zaawansowanej akcji porodowej nie ma możliwości bieżącej oceny aktywności FVIII lub FIX, to podstawą strategii działania stają się wyniki pomiarów uzyskanych w III trymestrze ciąży oraz aktualne badanie układu krzepnięcia [12]. W czasie porodu u nosicielki hemofilii zaleca się utrzymywanie aktywności FVIII i FIX nie mniejszej niż 50 jm./dl [16]. Koncentrat niedoborowego czynnika krzepnięcia należy podać natychmiast po rozpoczęciu akcji porodowej, a w przypadku cięcia cesarskiego — przed rozpoczęciem zabiegu (tab. 1, 2).

Znieczulenie zewnątrzoponowe u nosicielek hemofilii wiąże się ze zwiększonym ryzykiem 
powikłań neurologicznych wynikających $z$ krwawienia do rdzenia. Mimo to większość ekspertów uważa, że można je bezpiecznie wykonać, jeśli aktywność niedoborowego czynnika krzepnięcia wynosi 50 j.m./dl i więcej [11, 12, 15, 16]. Do czasu całkowitego ustąpienia znieczulenia jest zalecana regularna ocena neurologiczna. Usunięcie cewnika $z$ przestrzeni zewnątrztwardówkowej przeprowadza się przy osoczowej aktywności FVIII i FIX $50 \mathrm{jm} . / \mathrm{dl}$ i więcej $[10,12]$.

Sposób zakończenia ciąży u nosicielek hemofilii od wielu lat pozostaje przedmiotem dyskusji. Według obowiązujących zaleceń hemofilia u płodu nie jest przeciwwskazaniem do porodu naturalnego $[9,11,12,24]$. Podejmując decyzję o sposobie poro$\mathrm{du}$, bierze się pod uwagę wskazania położnicze oraz ryzyko powikłań — zarówno u matki, jak i u noworodka. Główne zagrożenia dla noworodka chorego na hemofilię to obrażenia głowy, których wynikiem mogą być podskórne wylewy krwi, krwotok podczepcowy (wynaczynienie krwi ponad okostną objawiające się obrzękiem owłosionej skóry głowy), krwiak podokostnowy (zbiornik wynaczynionej krwi z naczyń penetrujących z kości do okostnej) oraz — najbardziej niebezpieczne dla życia dziecka - krwawienie wewnątrzczaszkowe [24, 25]. Według danych opublikowanych przez Kulkarni i wsp. [26] krwawienie wewnątrzczaszkowe występowało u 2,8\% chłopców $z$ hemofilią urodzonych drogami natury i u $0,2 \%$ urodzonych poprzez planowe cięcie cesarskie. Między innymi dlatego wielu ekspertów zaleca, by u nosicielek hemofilii rozwiązywać ciążę planowym cięciem cesarskim [11, 15, 25]. Za tym sposobem zakończenia ciąży przemawia także fakt, że trudno przewidzieć przebieg porodu naturalnego, a jego przedłużenie (zwłaszcza drugiego okresu) lub konieczność przeprowadzenia porodu zabiegowego znacznie zwiększają ryzyko powikłań krwotocznych. Ryzyko niebezpiecznych powikłań zwiększa się również w przypadku cięcia cesarskiego wykonanego w późnym okresie ze wskazań nagłych. Duży wpływ na wynik porodu oraz bezpieczeństwo dziecka ma współdziałanie specjalistów zaangażowanych w opiekę nad ciężarną nosicielką hemofilii. Planowe cięcie cesarskie, przeprowadzone $\mathrm{w}$ ustalonym wcześniej terminie, ułatwia koordynację działań i szybką diagnostykę hemofilii u noworodka, a także właściwe monitorowanie leczenia (dostępność hematologa, diagnosty laboratoryjnego; zabezpieczenie koncentratu czynnika krzepnięcia) [25]. Natomiast zwolennicy porodu siłami natury argumentują, że stanowi on naturalny sposób zakończenia ciąży i wiąże się z niższym ryzykiem krwotoku u matki w porównaniu $z$ za- biegiem operacyjnym, jakim jest cięcie cesarskie. Tym niemniej w przypadku porodu naturalnego także istnieje ryzyko powikłań krwotocznych. Na przykład krwiaki krocza po porodzie drogą naturalną ponad 10-krotnie częściej obserwuje się u nosicielek hemofilii niż u pozostałych kobiet [24, 25]. Wydaje się, że najbardziej uzasadnione jest indywidualne podejście do ciężarnej nosicielki hemofilii, rozważenie możliwych zagrożeń dla matki i płodu oraz wybór najbezpieczniejszego sposobu zakończenia ciąży. W przypadku planowania porodu siłami natury najważniejsze są dokładna ocena ginekologiczna pod kątem położniczych czynników ryzyka powikłań oraz unikanie przedłużającego się drugiego okresu porodu [25]. Podczas porodu przeciwwskazane są także inwazyjne metody monitorowania i używanie kleszczy czy próżnociągów $[3,11,12,15]$. Istotne jest przedstawienie ciężarnej nosicielce hemofilii możliwych rozwiązań - ich wad oraz zalet $[11,15]$.

Nosicielki hemofilii są narażone na ciężkie krwotoki poporodowe (PH,postpartum hemorrhage), które są najczęstszą przyczyną zgonów kobiet w okresie połogu [11, 12]. Krwotok poporodowy definiuje się jako utratę ponad $500 \mathrm{ml}$ krwi w przypadku porodu drogami natury i ponad $1000 \mathrm{ml}$ po cięciu cesarskim. Krwotok pierwotny występuje do 24 godzin po porodzie, a wtórny - do 6 tygodni po porodzie. Pierwotne krwotoki poporodowe występują u 22\%, zaś wtórne u 9-11\% nosicielek hemofilii [13]. Zwiększone ryzyko powikłań krwotocznych, zwłaszcza opóźnionych, wynika ze spadku aktywności FVIII, który rozpoczyna się zwykle od 3. doby po porodzie. Powrót FVIII:C do wartości sprzed ciąży następuje w ciągu 7-21 dni [11]. $\mathrm{Z}$ tego powodu w okresie poporodowym powinno się monitorować aktywność FVIII lub FIX i utrzymywać ją na poziomie $50 \mathrm{jm}$./dl lub powyżej tej wartości. Postępowanie to należy kontynuować do czasu zagojenia rany, tj. w przypadku porodu siłami natury - minimum 3-4 dni, a cięcia cesarskiego - minimum 5-7 dni [10-12]. U nosicielek hemofilii po cięciu cesarskim nie zaleca się rutynowo farmakologicznej profilaktyki przeciwzakrzepowej, co nie oznacza, że w indywidualnych przypadkach (obecne dodatkowe czynniki ryzyka żylnej choroby zakrzepowo-zatorowej) nie można jej zastosować $[15,27]$.

W profilaktyce i leczeniu krwotoków poporodowych u nosicielek hemofilii, oprócz koncentratów niedoborowych czynników krzepnięcia i ewentualnie DDAVP (hemofilia A), wykorzystuje się także TXA. Dawkowanie koncentratów i DDAVP $\mathrm{w}$ omawianym wskazaniu podano w tabelach 1 i 2 . 


\section{Postępowanie u noworodka}

U noworodków aktywność czynników krzepnięcia zależnych od witaminy K (II, VII, IX, X), oraz FXI i FXII jest fizjologicznie zmniejszona. Jest to spowodowane niedojrzałością hepatocytów oraz niedoborem witaminy $\mathrm{K}$. U donoszonych noworodków aktywność FIX wynosi około 50\% wartości stwierdzanych u osób dorosłych [10]. Fizjologiczne zmniejszenie aktywności FIX sprawia, że u wcześniaków, donoszonych noworodków i niemowląt stosuje się różne normy referencyjne czasu częściowej tromboplastyny po aktywacji (APTT, activated partial thromboplastin time) [28]. Aktywność FVIII u noworodków urodzonych o czasie oraz u wcześniaków nie różni się od wartości u osób dorosłych [29].

U noworodków $z$ potwierdzoną $\mathrm{w}$ badaniach prenatalnych hemofilią oraz u synów nosicielek, które nie zdecydowały się na diagnostykę prenatalną, już podczas porodu należy oznaczyć aktywność FVIII lub FIX we krwi pępowinowej [11, 29]. Postępowanie to pozwala zapobiec ewentualnemu nadmiernemu krwawieniu po nakłuciu żyły obwodowej noworodka, lecz jest obarczone ryzykiem zanieczyszczenia pobranej próbki materiałem pochodzenia matczynego. $\mathrm{W}$ przypadku takiego podejrzenia pobiera się nie więcej niż $0,5-1,0 \mathrm{ml}$ krwi żylnej dziecka, gdyż pobranie większej objętości krwi mogłoby prowadzić do niedokrwistości $[9,11,29]$. Do momentu wykluczenia skazy krwotocznej u noworodka nie powinno się wykonywać iniekcji domięśniowych. Można natomiast podać witaminę K doustnie i bezpiecznie wykonać szczepienia podskórne [12, 13, 29].

Stwierdzenie zmniejszonej aktywności FVIII $\mathrm{u}$ noworodka potwierdza rozpoznanie hemofilii A. W łagodnych postaciach hemofilii A może ona wynosić tylko nieco poniżej $40 \mathrm{jm} . / \mathrm{dl}$ i konieczne jest wtedy ponowne wykonanie badania po 6 . miesiącu życia, gdy wątroba dziecka osiąga pełną sprawność $\mathrm{w}$ procesie syntezy czynników krzepnięcia. W ciężkiej i umiarkowanej hemofilii B rozpoznanie można ustalić na podstawie oznaczeń FIX:C przeprowadzonych w okresie noworodkowym. Natomiast $\mathrm{w}$ łagodnej hemofilii B, z powodu fizjologicznego zmniejszenia aktywności FIX u noworodków i niemowląt, niezbędne jest powtórne oznaczenie między 3. a 6. miesiącem życia [28, 29].

Największym zagrożeniem dla nowo narodzonego chłopca $z$ ciężką hemofilią są krwawienia wewnątrz- i zewnątrzczaszkowe, które występują u 1-4\% noworodków z tą skazą krwotoczną [29]. Główne czynniki ryzyka krwawienia o takim umiej- scowieniu to przedłużający się drugi okres porodu, poród instrumentalny, a także poród przedwczesny $[12,29,30]$. W wielu przypadkach pierwsze objawy krwawienia wewnątrzczaszkowego udaje się wykryć za pomocą nieinwazyjnego i łatwo dostępnego badania - ultrasonografii (USG) przezciemiączkowej. Należy ją wykonać u wszystkich noworodków $z$ ciężką i umiarkowaną hemofilią przed wypisaniem ze szpitala [11, 29]. Dodatkowo zaleca się tomografię komputerową (CT, computed tomography) lub rezonans magnetyczny (MRI, magnetic resonance imaging), jeśli - mimo prawidłowego wyniku badania USG — występują objawy sugerujące krwawienie śródczaszkowe [29]. Warto nadmienić, że USG przezciemiączkowe u noworodków cechuje się małą czułością, zwłaszcza w krwiakach podtwardówkowych i krwiakach zlokalizowanych w tylnym dole czaszki [11]. Podejrzewając aktywne krwawienie u dziecka $z$ rozpoznaną hemofilią, należy natychmiast podać rekombinowany koncentrat niedoborowego czynnika krzepnięcia w dawce zapewniającej aktywność w osoczu wynoszącą $100 \mathrm{jm} . / \mathrm{dl}$ [12, 29, 31]. W przypadku dobrej odpowiedzi na leczenie po tygodniu dawki koncentratu zmniejsza się tak, aby FVIII:C lub FIX:C utrzymywała się na poziomie $50 \mathrm{jm} . / \mathrm{dl}$ lub wyższym. Wylewy śródczaszkowe wymagają leczenia substytucyjnego koncentratem czynnika krzepnięcia, co najmniej przez 2-3 tygodnie, a po ich ustąpieniu jest zalecana regularna substytucja niedoborowego czynnika krzepnięcia w ramach długoterminowej profilaktyki przeciwkrwotocznej $[16,31]$.

Noworodki, w porównaniu $z$ osobami dorosłymi, mogą wymagać podawania większych dawek koncentratów FVIII i FIX, ponieważ klirensy FVIII i FIX są większe u dzieci niż u dorosłych [29]. Niestety nie ma popartych dowodami naukowymi rekomendacji dotyczących dawkowania koncentratów czynników krzepnięcia ( $\mathrm{z}$ uwzględnieniem farmakokinetyki) w tej grupie wiekowej. W większości przypadków podstawą terapii jest doświadczenie pochodzące $z$ leczenia starszych dzieci, dorosłych oraz z opisów pojedynczych przypadków [29, 32,33]. Zawsze obowiązuje laboratoryjna kontrola skuteczności leczenia.

Krótkoterminową wysokodawkowaną profilaktykę rekombinowanym koncentratem FVIII lub FIX należy rozważyć u noworodków z potwierdzoną ciężką hemofilią, jeśli występują dodatkowe czynniki ryzyka krwawienia, takie jak: ciężki poród, przedłużający się drugi okres porodu ( $>3 \mathrm{~h}$ u pierwiastek i $>2 \mathrm{~h} \mathrm{u}$ wieloródek), wcześniactwo oraz obecność podskórnych wylewów krwi 
w obrębie głowy [29]. W takich sytuacjach większość ekspertów zaleca utrzymywanie aktywności niedoborowego czynnika krzepnięcia w osoczu dziecka na poziomie $100 \mathrm{jm} . / \mathrm{dl}$ i wyższym, a czas leczenia uzależnia od stanu klinicznego dziecka [30, 32, 33]. W Polsce pacjenci z potwierdzoną ciężką hemofilią A i B są objęci długoterminową profilaktyką krwawień [34].

\section{Podsumowanie}

Opiekę nad nosicielką hemofilii w okresie ciąży i porodu powinien sprawować zespół doświadczonych klinicystów złożony $z$ ginekologa, hematologa $i$ anestezjologa. Poradnictwo genetyczne umożliwia tym pacjentkom podjęcie świadomej decyzji dotyczącej planowania rodziny, a właściwa opieka pozwala uchronić przed groźnymi — zarówno dla matki, jak i nowo narodzonego dziecka - powikłaniami krwotocznymi. Szczególnie niebezpiecznym momentem dla matki i dziecka jest okres okołoporodowy. Brakuje dużych, prospektywnych badań klinicznych, których wyniki dostarczyłyby jednoznacznych danych na temat rzeczywistego ryzyka wystąpienia powikłań w przypadku porodu naturalnego i planowego cięcia cesarskiego u nosicielek hemofilii. Dlatego najbardziej uzasadnione jest indywidualne podejście do ciężarnej nosicielki hemofilii, rozważenie możliwych zagrożeń dla matki i płodu oraz wybranie najbezpieczniejszego sposobu zakończenia ciąży. Istotną rolę odgrywa odpowiednia relacja $z$ kobietą $\mathrm{w}$ ciąży, poinformowanie jej o możliwych powikłaniach oraz uzasadnienie wyboru sposobu rozwiązania ciąży. U noworodków płci męskiej zaleca się oznaczenie aktywności FVIII lub FIX we krwi pępowinowej oraz obserwację w kierunku oznak krwawienia śródczaszkowego. Chłopcy z rozpoznaną hemofilią wymagają objęcia opieką w ośrodkach leczenia hemofilii.

\section{Piśmiennictwo}

1. Windyga J. Hemofilie A i B. W: Dmoszyńska A. (red). Wielka Interna. Hematologia. Wydawnictwo Medical Tribune Polska, Warszawa 2011: 608-630.

2. Kadir R.A., Lee C.A. Obstetrics and gynecology: hemophilia. W: Christine A., Lee C.A., Berntorp E.E., Hoots K.W. (red). Textbook of hemophilia. $2^{\text {nd }}$ edition. Willey-Blackwell, Philadelphia 2010: 269-277.

3. Srivastava A., Brewer A.K., Mauser-Bunschoten E.P. i wsp. Treatment Guidelines Working Group on behalf of the World Federation of Hemophilia. Guidelines for management of hemophilia. Haemophilia 2013; 19: e1-e47.

4. Mauser-Bunschoten E.P. Symptomatic carriers of hemophilia. W: Schulman S. (red). Treatment of hemophilia. World Federation of Hemophilia. Dostępne na: www.wtf.org. Data dostępu 31.12.2008.
5. World Federation of Hemophilia. Carriers and women with hemophilia World Federation of Hemophilia, Montréal. 2012; 1-19. Dostępne na: http://www1.wfh.org/publication/files/pdf-1471.pdf. Data dostępu 29.03.2016.

6. White G.C., Rosendaal F., Aledort L.M. i wsp.; Factor VIII and Factor IX Subcommittee. Definitions in hemophilia. Recommendation of the scientific subcommittee on factor VIII and factor IX of the scientific and standardization committee of the International Society on Thrombosis and Haemostasis. Thromb. Haemost. 2001; 85: 560.

7. Ross J. Perspectives of haemophilia carriers. Haemophilia 2000; 6: $41-45$.

8. Winikoff R., Lee C. Hemophilia carrier status and counseling the symptomatic and asymptomatic adolescent. J. Pediatr. Adolesc. Gynecol. 2010; 23: 43-47.

9. Giangrande P.L.F. Management of pregnancy in carriers of haemophilia. Haemophilia 1998; 4: 779-784.

10. Chi C., Lee C.A., Shiltagh N. i wsp. Pregnancy in carriers of hemophilia. Haemophilia 2008; 14: 56-64.

11. Hu Q.F.Y., Kadir R.A. Management of pregnancy, labour and delivery in women with inherited bleeding disorders. Haemophilia 2011; 17: 20-30.

12. Lee C.A., Chi C., Pavord S. i wsp. The obstetric and gynaecological management of women with inherited bleeding disorders review with guidelines produced by a taskforce of UK Haemophilia Centre Doctors' Organization. Haemophilia 2006; 12: 301-336.

13. Peyvandi F., Garagiola I., Menegatti M. Gynecological and obstetrical manifestations of inherited bleeding disorder in women. J. Thromb. Haemost. 2011; 9: 236-245.

14. Siboni S.M., Spreafico M., Calo L. i wsp. Gynecological and obstetric problems in women with different bleeding disorders. Haemophilia 2009; 15: 1291-1299.

15. Kadir R.A., Davies J., Winikoff R. i wsp. Pregnancy complications and obstetric care in women with inherited bleeding disorders. Haemophilia 2013; 19: 1-10.

16. Windyga J., Chojnowski K., Klukowska A. i wsp. Polskie zalecenia postępowania we wrodzonych skazach krwotocznych na tle niedoboru czynników krzepnięcia. Część I. Acta Haemat. Pol. 2008; 39: 537-564.

17. Mannucci P.M. Desmopressin (DDAVP) in the treatment of bleeding disorders: first 20 years. Blood 1997; 90: 2515-2521.

18. Trigg D.E., Sterigiotou I., Peitsidis P., Kadir R.A. A systematic review: the use of desmopressin for treatment and prophylaxis of bleeding disorders in pregnancy. Haemophilia 2012; 18: 25-33.

19. Peitsidis P., Kadir R.A. Antifibrinolytic therapy with tranexemic acid in pregnancy and postpartum. Expert Opin. Pharmacother. 2011; 12: 503-516.

20. Odnoczko E., Windyga J. Badania genetyczne w diagnostyce hemofilii A. Hematologia 2014; 5: 1-10.

21. Belvini D., Salviato R., Acquila M. i wsp. Prenatal diagnosis of haemophilia B: the Italian experience. Haemophilia 2013; 19: 898-903.

22. Kessler L., Adams R., Mighion L., Walther S., Ganguly A. Prenatal diagnosis in haemophilia A: experience of the genetic diagnostic laboratory. Haemophilia 2014; 20: e384-e391.

23. Baranowski W. Przetaczanie krwi i jej składników w położnictwie i ginekologii. W: Korsak J., Łętowska M. (red). Transfuzjologia kliniczna. Wydawnictwo $\alpha$-medica press, Bielsko-Biała 2009: 155-166.

24. Ljung R. The optimal mode of delivery for the haemophilia carrier expecting an affected infant is vaginal delivery. Haemophilia 2010; 16: 415-419. 


\section{Hematologia 2016, tom 7, nr 1}

25. James A.H., Hoots K. The optimal mode of delivery for the haemophilia carrier expecting an affected infant is caesarean delivery. Haemophilia 2010; 16: 420-424.

26. Kulkarni R., Soucie J.M., Lusher J. i wsp. Sites of initial bleeding episodes, mode of delivery and age of diagnosis in babies with haemophilia diagnosed before the age of 2 years: a report from The Centers for Disease Control and Prevention's (CDC) Universal Data Collection (UDC) project. Haemophilia 2009; 15: 1281-1290.

27. Przkora R., Euliano T.Y., Roussos-Ross K., Zumberg M., Robicsek S.A. Labor and delivery in a patient with hemophilia B. Int. J. Obstet. Anesth. 2011; 20: 250-253.

28. Thomas A.E., Chalmers E. The neonate with hemophilia. W: Christine A., Lee C.A., Berntorp E.E., Hoots K.W. (red). Textbook of hemophilia. $2^{\text {nd }}$ edition. Willey-Blackwell, Philadelphia 2010: 111-117.

29. Chalmers E., Williams M., Brennand J. i wsp.; on behalf of the Paediatric Working Party of the United Kingdom Haemophilia
Doctors' Organisation. Guideline on the management of haemophilia in the fetus and neonate. Br. J. Haematol. 2011; 154: 208-215.

30. Bidlingmaier C., Bergamnn F., Kurnik K. Haemophilia in two premature infants. Eur. J. Pediatr. 2005; 164: 70-72.

31. Ljung R.C.R. Intracranial haemorrhage in haemophilia A and B. Br. J. Haematol. 2007; 140: 378-384.

32. Kraft K.E., Verlaak R., Van Heijst A.F.J., Novakova I., Brons P.P.T. Management of haemophilia in three premature infants. Haemophilia 2008; 14: 378-380.

33. Gale R.F., Hird M.F., Colvin B.T. Management of premature infant with moderate haemophilia A using recombinant factor VIII. Haemophilia 1998; 4: 850-853.

34. Klukowska A., Urasinski T., Janik-Moszant A. i wsp. Prophylaxis in children with haemophilia - the Polish experience. Haemophilia 2014; 20: e108-e110. 